\title{
Glacial Lake Outburst Flood Disasters and Integrated Risk Management in China
}

\author{
Shijin Wang ${ }^{1} \cdot$ Lanyue Zhou $^{1}$
}

Published online: 7 December 2017

(c) The Author(s) 2017. This article is an open access publication

\begin{abstract}
High-risk areas for glacial lake outburst flood (GLOF) disasters in China are mainly concentrated in the middle-eastern Himalayas and Nyainqêntanglha (Nyenchen Tanglha Mountains), Tibetan Plateau. In the past 20 years, glaciers in these regions have retreated and thinned rapidly as a response to regional climate warming, leading to the formation of new glacial lakes and the expansion of existing glacial lakes. These areas are located in the border belt between the Indian and the Eurasian plates, where tectonic seismic activity is also frequent and intense. Earthquakes have often compromised the stability of mountain slopes, glaciers, and moraine dams, resulting in an imbalance in the state of glacial lakes and an increase of loose materials in valleys. It is foreseeable that the possibility of GLOFs and disaster occurrence will be great in the context of frequent earthquakes and continued climate warming. This article presents the temporal and spatial characteristics of GLOF disasters, as well as the conditions and mechanisms of GLOF disaster formation, and proposes an integrated risk management strategy to cope with GLOF disasters. It aims to facilitate the mitigation of the impacts of GLOF disasters on mountain economic and social systems, and improve disaster risk analysis, as well as the capability of risk management and disaster prevention and reduction.
\end{abstract}

Keywords China - Glacial lake outburst flood disasters · Risk management $\cdot$ Tibetan Plateau

Shijin Wang

xiaohanjin@126.com

1 State Key Laboratory of Cryospheric Sciences, Northwest Institute of Eco-Environment and Resources, Chinese Academy of Sciences, Lanzhou 730000, Gansu, China

\section{Introduction}

Compared to a slow warming trend in the first half of the twentieth century, the intensity and duration of global warming since the 1970s has become increasingly significant, and the scope and extent of the warming influence is increasing, with growing frequency and intensity of, and losses from climatic events or disasters (Marshall 2011; Wang et al. 2015). Glacial lake outburst floods (GLOFs) are natural hazards caused by indirect factors of climate change, volcanic eruptions, seismic activities, and so on, and are characterized by their sudden occurrence, high flood peak, large discharge, strong destructiveness, and short duration with a widespread range. GLOFs are much larger than normal rainfall and nival floods and can mobilize large volumes of sediment from the moraine dams and the stream channels below the dams (Kershaw et al. 2005). The effects of GLOF disasters (especially debris flows) are difficult to predict, and seriously affect the lives and properties of residents in the downstream communities, as well as the transportation, infrastructure, agriculture, ice and snow tourism, and national defense systems in cold regions.

GLOF disasters worldwide have mainly occurred in the Himalayas, the Peruvian Cordillera Blanca, Chilean Patagonia, the Canadian Rockies, the Alps, and the Tianshan Mountains (Dussaillant et al. 2010; Shrestha and Aryal 2010; USAID 2014; Wang and Zhang 2013). During the past 65 years, over 21 GLOF disasters have been recorded and nearly 30,000 people have been killed in the Peruvian Cordillera Blanca (Carey 2005, 2008, 2010), for example. GLOFs are considered the most important glacier-related hazards in terms of direct damage potential. However, risk management measures are extremely limited in these areas, and the potential GLOF damage is 
worrisome. Throughout the Himalayas and Nyainqêntanglha, from 1998 to 2006, simple manual excavation measures were undertaken to reduce lake water levels in only four potentially dangerous glacial lakes (the Rolpa Lake in Nepal in 1998, the Luggye and Raphsthreng lakes in Bhutan in 1998, and the Longbasaba Lake in China in 2006). After that, the projects were forced to stop because of financial or other reasons.

Existing studies show that the Tibetan Plateau has experienced a significant warming trend in the past decades - the rate of warming is significantly higher than that of the global average, and the climate and environment have undergone major changes ( $\mathrm{Li}$ et al. 2010). With regional warming, mountain glaciers have retreated and thinned rapidly, leading to the formation of new glacial lakes and the expansion of existing glacial lakes. As of 2006, there were 2483 glacial lakes (larger than $0.014 \mathrm{~km}^{2}$ ) with a total area of $366.56 \mathrm{~km}^{2}$ in the Tibet Autonomous Region (southern Tibetan Plateau). There were 329 moraine-dammed lakes (larger than $0.02 \mathrm{~km}^{2}$ ) with a total area of $125.43 \mathrm{~km}^{2}$ in the Chinese Himalayas in the 2010s-of these, 116 lakes with a total area of $49.49 \mathrm{~km}^{2}$ have been identified as potentially dangerous glacial lakes (Wang et al. 2015).

The risk of GLOFs and derivative disaster occurrences is high given frequent earthquakes and continued warming. The occurrence of GLOF disasters is due to both natural and social factors and their interactions. Risk factors not only include the hazard of glacial lake outburst (outburst probability), but also involve the related vulnerability and adaptation capacity of exposed elements such as population, road networks, and other infrastructure. Previous studies have focused mainly on glacial lake distribution and evolution, the triggering factors and probability estimation of glacial lake outburst, and the estimation and simulation/prediction of the maximum discharge. However, the mechanism of glacial lake failure and disaster formation and the integrated risk management have been less considered comprehensively in the risk assessment of GLOF disasters. This article briefly examines the temporal and spatial characteristics of GLOF disasters and the conditions and mechanisms of GLOF disaster formation, and proposes an integrated risk management strategy to cope with GLOF disasters. The purpose is to improve the analysis of GLOF disaster risk, enhance disaster prevention and risk management capabilities, protect mountainous infrastructure security, guide mountain land and urban planning, and make disaster prevention and mitigation plans.

\section{Temporal and Spatial Characteristics of Glacial Lake Outburst Flood Disasters}

Past records and reports indicate that at least 40 GLOF disasters have occurred in the middle-eastern Chinese Himalaya and Nyainqêntanglha range since 1935 (Wang and Zhang 2013)—mainly in the 1960s, 1980s, 1990s, and 2000s (the number of disasters in these periods reached 7 , 9,5 , and 10 times respectively, accounting for more than three quarters of the total). Fewer disasters (2, 2, and 3) occurred in the 1930s, 1950s, and 1970s; and only one disaster occurred in each period in the 1940s and the 2010s. Among the 40 disaster events, 25 occurred in the Himalayas, 14 in Nyainqêntanglha, and 1 in the Tanggula Mountain, and 59\% occurred on the southeastern slope of the Tibetan Plateau in the subtropical monsoon climate zone and the convergence belt of continental and temperate glaciers. Rapid population growth and livestock, arable land, and regional infrastructure developments in these two areas exposed assets to high potential risk of GLOFs. In the last 20 years, Zanaco Lake (26-28 May 1995), Chongbaxiaco Lake (6 October 2000), Jialongco Lake (23 May and 29 June 2002), Degaco Lake (18 September 2002), and Zhemaico Lake (3 July 2009) in the middle-eastern Himalaya, and Cilaco Lake (9 July 2009) and Recireco Lake (5 July 2013) in middle Nyainqêntanglha outburst and caused huge casualties and property losses (Wang et al. 2015). Especially, on 5 July 2013, the Recireco Lake (with an area of about $0.57 \mathrm{~km}^{2}$ ) outburst occurred in the eastern Nyainqêntanglha ranges and then formed mudslides. As a result, in Zhongyu Township of Jiali County in the Tibet Autonomous Region, 238 families (1160 people) were affected; some people were reported missing, many buildings were destroyed, and some infrastructures were damaged. The total economic loss was estimated at RMB 200 million yuan.

\section{Categories of Glacial Lake Failure}

The formation and occurrence of GLOF disasters is often subject to various factors, divided into external (snow/ice/ rock avalanches, landslides, rainstorms, glacier advance, earthquakes, snow and ice meltwater), and internal (ablation of buried ice within moraine dams, meltwater, seepage/piping, and so on) (Mckillop and Clague 2007; Wang and Jiao 2015). External triggering factors often result in the imbalance of the state of a glacial lake, and glacial lake outburst is often caused by a particular factor or multiple factors jointly. According to the failure mechanisms, glacial lake outbursts can be divided into five categories: 
1. Outburst floods triggered by wave overtopping. When snow/ice/rock avalanches enter a glacial lake, the water level rises and the lake surface generates displacement waves; the superimposed surges submerge the moraine dam crest, extrude the unstable dam body, and the overflowing water initiates the breach of the moraine dam without incision of the outlet channel. Rainstorms and glacier meltwater can also cause the water level to rise and the flow rate to increase (Kershaw et al. 2005). When the strength of the water that escapes from the lake and the incision of the outlet channel exceed a certain threshold, glacial lake outburst occurs.

2. Outburst floods triggered by seepage/piping. When the buried ice within a moraine dam melts or seepage erodes the dam body, the piping channel is expanded and sometimes causes the dam body to sink, eventually resulting in glacial lake outburst.

3. Outburst floods triggered by earthquake. When an earthquake occurs, moraine dams can suddenly collapse.

4. Outburst floods triggered by flowing water erosion from the next valley. When flowing water erosion from the next valley exists at the bottom of a moraine dam, the dam body is washed out, its stability is weakened, and eventually part of the moraine dam will suddenly break.

5. Outburst floods triggered by various combined factors. When snow/ice/rock bodies enter a glacial lake, superimposed surges occur and produce overtopping floods that further erode the incision of the outlet channel, causing dam crest collapse and outburst floods.

\section{Conditions and Mechanisms of Glacial Lake Outburst Flood Disaster Formation}

Glacial lake outbursts do not necessarily result in disasters. Generally, the formation and occurrence of a GLOF disaster is based on certain conditions coming together that are related to climate, water source, material source, terrain, and the elements that would be affected by the glacial lake outburst. The Alpine areas of the Tibetan Plateau have experienced a significant warming trend, with a temperature increase of $1.013{ }^{\circ} \mathrm{C}$ in the past 50 years. In the 1990s-2010s period, total moraine-dammed lake area (larger than $0.02 \mathrm{~km}^{2}$ ) increased by $26 \%$ in the Himalaya and Nyainqêntanglha (Wang et al. 2015), which provides plenty of water sources for GLOFs. Past studies (Chen et al. 2007; Wang and Jiao 2015) have also shown that GLOF disasters have occurred mostly in the warm season and the transitional period from cold to warm. Of the 40 GLOF disasters, for example, 28 occurred from July through September. In this period, high temperatures and abundant rainfall often make glaciers (especially the glacier tongues) melt strongly. When glacier meltwater or ice avalanches enter lakes, the sudden rise of water level and the huge surges or shock waves can cause moraine dam breaches and lake outbursts. Short-term, high-intensity rainfall is an especially important factor that can cause lake outbursts.

Earthquakes often compromise the stability of glaciers and moraine dams. But they also damage the geotechnical stability of rocks and generate loose materials on valley floors and sides, providing the material source for GLOF mudslide formations. The steep slopes of glaciers and glacier tongues contribute to ice body advances and collapses, causing surges and potentially destroying moraine dams. Narrow terminal moraine dam crests and their low stability, high lateral moraine ridges and slopes, and large longitudinal slopes of downstream valleys are also important terrain conditions for the formation of GLOFs or debris flows.

The middle-eastern Himalaya and Nyainqêntanglha valley areas, with elevations ranging from 2000 to $4000 \mathrm{~m}$, have a relatively dense population, human settlements, economic activities, road networks, and other infrastructures compared to other areas on the Tibetan Plateau. Their land area is less than $25 \%$ of the total of the Tibet Autonomous Region, but these areas account for more than $50 \%$ of the population (1.6 million people) and about $35 \%$ of the GDP (400 billion yuan) in the region. The LhasaNyingchi, Lhasa-Shigatse, and Sichuan-Tibet (to be built) Railways, and the Lhasa-Nyingchi and Milin-Baji highgrade highways are distributed here, as well as the 318 National Road and the 202, 204, 305, and 306 Provincial Roads. Although local communities in remote areas are located away from glacial lakes, they are often within the reach of GLOFs. Local residents' awareness of the threat from remote glacial lakes is relatively weak, and their ability to prevent GLOF disaster risks is extremely limited. These situations make them particularly vulnerable to GLOFs (Wang and Jiao 2015).

\section{Integrated Glacial Lake Outburst Flood Risk Management Strategies}

Preparedness ensures success and lack of preparedness spells failure. To live with risk, taking preventive measures is one guiding principle that is crucial for the management of any natural hazard-induced disaster risk. Glacial lake outburst is an event with low frequency, and its risk is often neglected by the local people and governments. It has been proven that the economic losses caused by GLOFs are 
much higher than the project costs to consolidate moraine dams and release flood waters in a timely manner. Predisaster prevention and control is far more effective than post-disaster recovery and reconstruction (Wang et al. 2015). GLOF disasters are mainly controlled by dangerous natural conditions of glacial lake outburst, while the vulnerability of disaster-affected elements is the social condition of GLOF disaster formation. Among GLOF risk factors, glacial lake outburst - the hazard - is very difficult or expensive to control, but the exposure area and vulnerability of the exposed elements downstream can be reduced by improving adaptation capacity and risk management through early warning and forecasting, establishing disaster reserves, disaster prevention engineering, improving medical services, emergency management, and disaster insurance.

The prerequisite for the prevention of glacial lake failure is to monitor glacial lake dynamics regularly, with a special focus on dangerous glacial lakes. But reasonable engineering measures (reinforcing or strengthening dangerous moraine dams, pumping, implementing siphon drainage measures, and excavating artificial drainage channels) that reduce lake capacity and reinforce moraine dams are the most effective to relieve or control the risk of GLOF disasters-what measures are most suitable depends mainly on the condition of the moraine dams, the outburst risk, and the engineering difficulties, among others (Cochachin 2013). Multiple stakeholders, including governments at all levels, experts, enterprises, nongovernmental organizations, and residents should participate in the whole process of prevention and reduction of GLOF disaster risks. In particular, community-based risk management mechanisms need to be established and mass-based monitoring and prevention systems need to be improved. But many rivers and glacial lakes have significant water supplies, hydropower, and recreation service functions, and we can also take advantage of these resources by building reservoirs, supplying irrigation water, and developing hydropower facilities, as well as using glacial lakes as tourist attractions. Especially, during the planning of mountain villages and towns, infrastructure development, and major engineering decision making, the government and its operating units must complete disaster risk assessment planning before construction, and keep all buildings, roads, and other infrastructure away from potentially dangerous glacial lakes in order to avoid unnecessary damage.

\section{Conclusion}

Although GLOFs are low-frequency events, resulting disasters have caused enormous loss and damage to lives, livestock, property, infrastructure, and the environment in downstream regions. In China, the middle-eastern Himalayas and Nyainqêntanglha are two areas highly prone to GLOF disasters. However, risk management measures are extremely limited in these areas, and the potential damage from GLOF disasters is significant. At present, there is an urgent need for government departments to implement engineering measures on all potentially dangerous glacial lakes. Especially, all buildings, roads, and other infrastructure in planning and construction processes should be located as far away as possible from these glacier lakes in order to avoid damage.

Acknowledgements This work was funded by the National Natural Science Foundation (41690143), the National Social Science Foundation of China (Grant No.14BGL137), the Technology Services Network Program of Cold and Arid Regions Environmental and Engineering Research Institute, the Chinese Academy of Sciences (HHS-TSS-STS-1501), and the National Basic Research Program of China (2013CBA01808). We also thank the anonymous reviewers and the journal editors for their helpful comments and suggestions, which considerably improved the final manuscript.

Open Access This article is distributed under the terms of the Creative Commons Attribution 4.0 International License (http://crea tivecommons.org/licenses/by/4.0/), which permits unrestricted use, distribution, and reproduction in any medium, provided you give appropriate credit to the original author(s) and the source, provide a link to the Creative Commons license, and indicate if changes were made.

\section{References}

Carey, M. 2005. Living and dying with glaciers: People's historical vulnerability to avalanches and outburst floods in Peru. Global Planet Change 47(2-4): 122-134.

Carey, M. 2008. Disasters, development, and glacial lake control in twentieth-century Peru. In Mountains: Sources of water, sources of knowledge, ed. E. Wiegandt, 181-196. Dordrecht: Springer.

Carey, M. 2010. In the shadow of melting glaciers: Climate change and Andean society. New York: Oxford University Press.

Chen, X.Q., P. Cui, Y. Li, Z. Yang, and Y.Q. Qi. 2007. Changes in glacial lakes and glaciers of post-1986 in the Poiqu River basin, Nyalam, Xizang (Tibet). Geomorphology 88: 298-311.

Cochachin, A. 2013. Glaciological and hydrological resources unit: Evolution of 10 glacial lakes in the Cordillera Blanca and the relationship to climate change over the past four decades. Presentation at the high mountains adaptation partnership workshop, 13 July 2013, in Huaraz, Peru. http://highmountains. org/workshop/peru-2013.

Dussaillant, A., G. Benito, W. Buytaert, P. Carling, C. Meier, and F. Espinoza. 2010. Repeated glacial-lake outburst floods in Patagonia: An increasing hazard? Natural Hazards 54(2): 469-481.

Kershaw, J.A., J.J. Clague, and S.G. Evans. 2005. Geomorphic and sedimentological signature of a two-phase outburst flood from moraine-dammed Queen Bess Lake, British Columbia, Canada. Earth Surface Processes and Land Forms 30(1): 1-25.

Li, L., X.G. Chen, Z.Y. Wang, W.X. Xu, and H.Y. Tang. 2010. Climate change and its regional differences over the Tibetan Plateau. Advances in Climate Change Research 6(3): 181-186 (in Chinese). 
Marshall, S.J. 2011. The cryosphere. Princeton: Princeton University Press.

Mckillop, R.J., and J.J. Clague. 2007. A procedure for making objective preliminary assessments of outburst flood hazard from moraine-dammed lakes in southwestern British Columbia. Natural Hazards 41(1): 131-157.

Shrestha, A.B., and R. Aryal. 2010. Climate change in Nepal and its impact on Himalayan glaciers. Regional Environmental Change 11(Suppl. 1): 65-77.

USAID (United States Agency for International Development). 2014. Glacial lake handbook-Reducing risk from dangerous glacial lakes in the cordillera Blanca, Peru. Washington, DC: USAID.
Wang, S.J., and S.T. Jiao. 2015. Evolution and outburst risk analysis of moraine-dammed lakes in the central Chinese Himalaya. Journal of Earth System Science 124(3): 567-576.

Wang, S.J., and T. Zhang. 2013. Glacial lakes change and current status in the central Chinese Himalayas from 1990 to 2010. Journal of Applied Remote Sensing. https://doi.org/10.1117/1. JRS.7.073459.

Wang, S.J., D.H. Qin, and C.D. Xiao. 2015. Moraine-dammed lake distribution and outburst flood risk in the Chinese Himalaya. Journal of Glaciology 61(225): 115-126. 